\title{
Ut'até ruky Rudolfa Fabryho v kontexte slovenského nadrealizmu
}

\author{
Jaroslava Šaková
}

\author{
ŠAKOVÁ, J.: Rudolf Fabry's Ut'até ruky (Severed hands) in the Context of \\ the Slovak Variant of Surrealism, Nadrealism \\ SLOVENSKÁ LITERATÚRA, vol. 68, 2021, no. 5, pp. 549-559 \\ DOI: https://doi.org/10.31577/slovlit.2021.68.5.5 \\ ORCID ID: 0000-0001-5235-102X
}

Key words: Nadrealism, experiment, tradition, playfulness, Rudolf Fabry

\begin{abstract}
Rudolf Fabry's first collection of poems, Ut'até ruky (Severed hands, 1935) was the first book published in the Aligátor series - one of the most distinct projects that accompanied the formation of the Nadrealist movement, the Slovak variant of Surrealism. Owing to the Aligátor series and other activities and products of the actors experimenting with Surrealist poetics, Nadrealism markedly shaped Slovak literature, visual arts, typography, and other forms of art. In result, it became an important movement in Slovak poetry, introducing new poetics which was not, however, met with understanding. The critical reception of Fabry's debut testifies to that. The debate concerning the new and the old - experiment and tradition - showed that it is crucial to recognise the degree to which Slovak Nadrealism was inspired by foreign authors and literatures (G. Apollinaire, Czech and French Surrealism). This article attempts at conceptualising Nadrealism in its objective contexts without which it cannot be adequately grasped.
\end{abstract}

Klúčové slová: nadrealizmus, experiment, tradícia, hravost', Rudolf Fabry 

a prebale prvého vydania básnickej zbierky Ut'até ruky od Rudolfa Fabryho (1905-1982) je uvedené, že bola vydaná nákladom združenia Aligátor $\mathrm{v}$ Bratislave $\mathrm{v}$ roku 1935. V rovnakom edičnom rade tohto vydavatel'stva vyšli postupne, v rokoch 1936-1940, nasledujúce knihy poézie: Móric Mittelmann Dedinský: Krivky (1936), R. Fabry: Vodné hodiny hodiny piesočné (1938), Vladimír Reisel: Vidím všetky dni a noci (1939), Ivan Kunoš: Podl'a hviezd menit'masky (1940). Pri aktuálnom čítaní edície sa vynára otázka vztahu dnes už kanonických autorov nadrealizmu, akými sú R. Fabry a V. Reisel, k básnikom, ktorých možno pracovne označit' ako ,autorov jednej zbierky“ - M. Dedinskému a I. Kunošovi. Signifikantný je pritom fakt, že R. Fabrymu v edícii vyšli hned' dve zbierky (v roku 1935 a v roku 1938), čím sa posilňuje obraz jeho významnejšieho postavenia v rámci nadrealistickej skupiny. Zdanie o tejto klúčovej Fabryho pozícii dodatočne upevnuujú aj memoárové texty tvorcov z okruhu nadrealizmu. ${ }^{1}$ Popri Fabrym sa o akési pomyselné vedúce miesto v slovenskom nadrealizme pravdepodobne pokúšal i M. M. Dedinský, ktorý dokonca vypracoval manifest Daniel v jame levovej. Oficiálne nebol publikovaný a z korešpondencie zainteresovaných vyplýva, že táto snaha Dedinského sa nedočkala širšej podpory. ${ }^{2}$

\section{Nadrealistická siet' väzieb}

V kontexte slovenského nadrealizmu nezohrával pojem skupiny či toho, kto je na jej pomyselnom čele, takú významnú úlohu ako napríklad v prípade českého či francúzskeho surrealizmu. V slovenskom nadrealizme išlo skôr o „siet' väzieb“, ktorá vznikla medzi jednotlivými autormi naprieč umeleckými druhmi (a napríklad i medzi teoretikmi). Ako napísal V. Reisel, „,generálny štáb“ nás nadrealistov a pridružených výtvarníkov, hercov a vedcov sa schádzal každý podvečer v Grandke a potom presídl'oval do Vel'kých Františkánov, kde sme mali vyárendovaný podlhovastý kumbál bez dvier a s dlhokánskym stolom, za ktorý sme sa vošli všetci, a často aj náhodní hostia z umeleckej branže“ (Reisel 2017:124). ${ }^{3}$ Pri využití sociologického konceptu Nialla Fergusona je možné vnímat' osobnost' R. Fabryho ako uzlový bod takejto siete, ktorý sa vyznačuje dôležitými spojeniami s jej ostatnými členmi:

„,Stupeň uzlu vyjadřuje to, co by se dalo nazvat, sociabilita': prostý počet vztahů, které má jedinec vi̊či druhým. ,Mezipoloha', formálně definovaná sociologem Lintonem Freemanem koncem 70. let, vyjádřuje, do jaké míry určitým uzlem

1 „Tuším ani jeden slovenský spisovatel' nemal tol'ko známych a priatel'ov ako on“ (Reisel 2017: 118); „na Fabryho bolo treba doslova pol'ovat'. Nie azda preto, že by trpel na konvenčné primadonstvo a ukazoval sa iba na ,reprezentačných plesoch'. Jednoducho jeho akčný rádius bol privel'ký, známosti prikošaté (Žáry 1988: 28-29).

2 V súhrne nadrealistickej korešpondencie uverejnenej v roku $1965 \mathrm{v}$ Slovenských pohladoch pod názvom Z letopisov nadrealizmu II. sa objavuje list Mikuláša Bakoša V. Reiselovi, v ktorom sa Bakoš v mene Fabryho zrieka účasti na Dedinského manifeste a označuje jeho kroky za nepremyslené.

3 Táto poznámka V. Reisela je významná $\mathrm{z}$ hl'adiska zachytenia kontaktov nadrealistov nielen s výtvarnými umelcami, ktoré sú tradične dobre popísané, ale aj s hercami, o ktorých sa hovorí pomenej. M. M. Dedinský v tejto súvislosti píše: „tam, kde nieto primárneho vplyvu avantgardy výtvarnej a javiskovej, či lepšie povedané: tam, kde výtvarné umenie nedospelo ešte $\mathrm{k}$ bodu, $\mathrm{v}$ ktorom je zrod avantgardy nevyhnutný, tam avantgarda slovesná spravidla nevzniká. Pre poznanie avantgardy literárnej na Slovensku je to konštatovanie dôležité“ (Dedinský 1963: 29). Komplexné uchopenie nadrealistických snáh je možné len v kontexte umeleckej spolupráce naprieč jednotlivými druhmi umenia. 
procházejí informace. Podobně jako lidé dojíždějící denně do práce soustředují dopravu do několika ucpaných křižovatek tím, že každý jednotlivě vyhledává nejkratší cestu k cíli, spoléhají se i lidé v síti často na klíčové jednotlivce, aby je propojili s jinak vzdálenými jedinci nebo skupinami. Jednotlivci s významnou mezipolohou nejsou nutně ti s největším počtem spojení, ale jsou to lidé s důležitými spojeními. (Jinými slovy nejde o to, kolik lidí znáte, ale o to, koho znáte)“ (Ferguson 2019: 44).

Nadrealisti však netvorili iba uzlové body siete, boli zároveň aj mostami medzi jednotlivými uzlami - nadrealistická skupina autorov takto premostovala napríklad svet literatúry so svetom výtvarného umenia. Miestom stretnutí boli kaviarne, ktoré sa stali dokonca potenciálnym rozlišovacím momentom v medzigeneračných stretoch nadrealistov so staršou generáciou. Predstavovali živý organizmus v centre umeleckého života, spôsob, akým sa hierarchické vzt'ahy menili na vztahy siete.

Dôležitost' siete väzieb, ktorú si nadrealisti dokázali sami vytvorit' a v rámci nej následne fungovat', sa ukázala aj pri vzniku a distribúcii nákladu zbierok edície Aligátor. Pri nadrealistickej vydavatel'skej činnosti išlo o performatívnost' takéhoto aktu - vydanie zbierok praktickým spôsobom potvrdzovalo spoluprácu autorov nadrealistického okruhu nielen v oblasti literatúry, ale aj v rámci prepojenia života a umenia (príkladom môžu byt' diskusie v Umeleckej besede, založenie Spolku pre vedeckú syntézu v bratislavskej kaviarni Metropol 23. júla 1937 či Večer nadrealistickej poézie, ktorý sa uskutočnil 28. februára 1939). Tieto umelecké gestá boli zároveň aj jednou z prvých ukážok odhodlania nadrealistov, manifestovaného v rozpätí rokov 1938 - 1942 vydaním štyroch zborníkov: Áno a nie (1938), Sen a skutočnost' (1940), Vo dne a v noci (1941), Pozdrav (1942). Navyše, $\mathrm{k}$ tvorivému gestu vydávania zbierok poézie, ich vizuálu a obsahových prvkov je potrebné pridat programovú prácu s odlíšením slovenskej verzie nadrealizmu od francúzskeho či českého surrealizmu.

Večery nadrealistickej poézie predstavovali podl'a dostupných zdrojov performancie svojho druhu doplnené o svetelné efekty a kulisy. Prepájanie literárnej avantgardy nadrealizmu s prejavmi iných umenív sebe spájalo inšpirácie zahraničnými kontextmi:

„Architekt Weinwurm, jeden z nezaslúžene zabúdaných kliesnitelov nových myšlienok a činov, dáva sa inšpirovat'Teigem a jeho rozvetvenou, do všetkých umeleckých disciplín zasahujúcou publikačnou činnost'ou a vydáva najprv architektonický časopis Forum, neskoršie širšie koncipovaný, hoci v podstate architektúre venovaný časopis Nová Bratislava. V oboch sa poskytuje priestor myšlienkam avantgardy a vytvára sa tak - hoci subtílna-základnica výtvarná pre vznik avantgardy literárnej“" (Dedinský 1963:34).

Pri prenikaní vplyvu českej avantgardy do slovenského kontextu zohrala úlohu Škola umeleckých remesiel v Bratislave, na ktorej prednášali českí príslušníci avantgardy (Jaromír Funke, Zdeněk Rossman), ale aj L'udovít Fulla a Mikuláš Galanda zo slovenského výtvarného prostredia. Otázka inšpiračných zdrojov z českého prostredia bola pertraktovaná aj pri výtvarných umelcoch, ktorí 
spolupracovali s básnikmi nadrealizmu. Zatial' čo v českom kontexte to bola jedna generácia, v slovenskom prostredí dochádzalo napríklad na pôde nadrealistických

\section{Utaté ruky ako prienik senzuálneho a vizuálneho}

Fabryho knižný debut, ale aj jeho d'alšia tvorba v rámci edície Aligátor ${ }^{5}$ predstavujú prelom v slovenskej typografii a celkovej úprave knižných diel. ${ }^{6} \mathrm{Na}$ základe toho zaujíma R. Fabry v rámci nadrealizmu zvláštne postavenie na prieniku literárnej a výtvarnej scény, ktoré sa síce vzájomne ovplyvňovali, ale nebývalo zvykom, aby sa jeden autor tak výrazne presadil v oboch týchto sférach.7

Zbierka Utáaté ruky sa člení na štyri časti - kritika o nich hovorí aj ako o cykloch, čím sa zdôrazňuje ich vnútorná koherencia. Prvá čast' Prolog obsahuje básne s pravidelným rýmom a so strofickým členením, čo možno interpretovat' ako premostenie autorovej časopisecky publikovanej tvorby a jeho debutu, s nižšou mierou parodickosti, ako je to v ostatných častiach zbierky. ${ }^{8}$ Táto čast'Ut'atých rúk bola kritikou interpretovaná vo vztahu k tradícii, ${ }^{9}$ avšak autor tu evokuje - už symbolicky názvom prvej básne $\mathrm{Na}$ križovatke - situáciu rozhodovania sa, ktorou cestou je najvhodnejšie vydat' sa. Namiesto prijatia či popretia tradície vystupuje do popredia samotný proces rozhodovania sa, ktorého postupným logickým výsledkom sú aj nasledujúce časti zbierky.

Častou Básne akoby autor mienil explicitne potvrdit', že aj texty s inovatívnejšou formou zahrnuté v tomto oddiele knihy sa môžu plným právom nazývat' básňami. Paleta textov sa v tretom cykle Prietržžánrovo rozširuje o lyrickú prózu Zo strateného zápisníka. Rovnako ako niektoré iné texty zbierky, prípadne ich časti, ktoré sú ponáškami na modlitby, detské riekanky či hádanky, aj táto lyrická próza

4 Týmito kritériami sú tematická mnohoznačnost', torzálnost', čiže tvarová a tematická neukončenost', zámerná náčrtovost' a náznakovost', z toho vyplývajúca neurčitost' vzt'ahov medzi zobrazovanými námetmi, ktorá je zdrojom poetického účinku (bližšie Dubnický 1941: 142-146).

5 R. Fabry bol autorom obálok štyroch z piatich zbierok vydaných v edícii a podielal sa aj na ich celkovej úprave či prípadnom dotvorení kolážami.

6 „Pozoruhodný je tiež jeho prínos slovenskej typografii, i ked'jeho dielo je v tejto oblasti nevel'ké. Najmä v prvotine Ut'até ruky sú typografické prvky, ktorými predbehol dobu“ (Longauer 2011: 311). Zaujímavá je tiež Fabryho práca s farbami, ked'od revolučnej červenej na prebale Ut'atých rúk a Kriviek prechádza cez modrú evokujúcu živel už z názvu Vodných hodin hodin piesočných až po žltú farbu obalu zbierky Vidím všetky dni a noci, ktorá môže predstavovat' striedanie svetla a tmy.

7 Popri Fabrym môžeme ešte spomenút' Ladislava Gudernu, ktorého lyrickej próze Vodnár mŕtvych vôd (1942) sa síce nedostalo zo strany kritiky vela pozornosti, ale ide o mnohovrstvový text vyznačujúci sa úzkym prepojením výtvarných a literárnych postupov.

8 „Názor, že v Prológu ide o paródiu starého typu básnenia, je rozšírený a často sa v slovenskej literárnej vede opakuje. Je pravda, že v Utáatých rukách nájdeme texty, v ktorých autor uplatňuje ,parodizačný princíp‘, pravdaže, nie v Prológu, čo Turčány dobre rozlišuje“ (Mikula 2014: 116).

9 „V Prológu sa Fabry nemohol vzdat' postimpresionistického (Felix), resp. postsymbolistického básnenia, ked'že k nemu ani nedospel. Nedištancuje sa tu od dosiahnutej literárnej kultivovanosti, ktorú avantgarda považovala za prekážku pre nové vnímanie sveta, iba sa ,vezie' na avantgardnej vlne antitradicionalizmu“ (Mikula 2014: 121). 
kombinuje niekol'ko prvkov rozličných žánrov (rozprávka, veštba, príhovor a iné), 553 ktorých uplatnenie je inherentnou súčast'ou tvorivej genézy autora. Miera inovatívnosti akoby sa v každej d'alšej časti zvyšovala-Prietrž má podtitul Automatické texty a poslednú čast' Fair play uvádza ambivalentne interpretovatel'né motto „za cenu umenia vzdávame sa umenia“. Tieto podtituly do istej miery korešpondujú s úsilím nadrealizmu o jasné deklarovanie novej poézie, ktorú prináša. Posledná čast' Fair play obsahuje napríklad básne s výrazne protivojnovou atmosférou - Vtačí snem („Deti deti / bomba letí / zastaví sa v cintore / všetky hroby poore“; Fabry 1935:54) a Dievčenský popevok (,Tisíc balíbonbony / jeden rozbaliuje bonbony / bude vojna bude vojna / tá vojna je jeho kojná“; Fabry 1935: 55), ${ }^{10} \mathrm{v}$ ktorých formálna hravost' riekankového rytmu slúži na vyjadrenie silného posolstva. Spojenie detí a priestoru cintorína evokuje Apollinairovu báseň Rýnska jesenná, kde deti a staré ženy zapalujú na sviatok Dušičiek sviečky na cintoríne.

Ďalším možným smerom interpretácie je archetypálny symbol vtáka z názvu Fabryho básne, ktorý sa neskôr opakovane znovuobjavuje tiež v autorovej druhej zbierke Vodné hodiny hodiny piesočné a býva spojený s kontrastom nového a starého, inovácie a tradície, napríklad cez symbol slávika alebo ako štylizácia v podobe litanickej chvály kohúta v časti básne Posledné. V nej sa na princípe polysémie toto slovo tematizuje vo viacerých významoch. Kohúta možno označit' čiastočne aj za prvok apollinairovského tematického repertoáru, ked'že v už spomínanej básni Rýnska jesenná sú verše „dnes žádný kohout nezpíval / Kykyryky““ (Apollinaire 2016:115). Apollinairovské inšpirácie sa tiahnu zbierkou od jej názvu až po záver, prispôsobené Fabryho autorskému rukopisu. Báseň Vtači snem nesie podtitul Škandál ktorý patrí do šlabikára a Paul Klee. V rámci inšpiračných zdrojov sa dá uvažovat aj o prípadnom odkaze na inovatívne princípy tvorby nemeckej umeleckej školy Bauhaus, kde Paul Klee pôsobil.

Záver zbierky tvorí text grafickej básne Bráno hlbokej ženskosti. Je zaliaty atramentovou škvrnou a napohlad vyzerá ako list, dokonca je podpísaný krstným menom autora (Š. Žáry ho dešifruje ako list farskej kuchárke Mare z básne Vtačí snem). Týmto spôsobom sa aktualizuje tradičný žáner (tu konkrétne epištolárny) v netradičnom prevedení, čo je postup typický pre zbierku Utáá ruky. Práve pri interpretáciách tejto básne sa zvykne zdôrazňovat' umelecká dvojdomost' R. Fabryho ako básnika aj ako vizuálneho umelca.

Štyri cykly zbierky sa okrem žánrového a obsahového hl'adiska líšia aj typografickým riešením: druhá a tretia čast' majú vel'mi podobnú typografiu, zatial' čo prvá a tretia čast' sa líšia typom písma, použitím kurzívy alebo zosilneného typu písma. Na takúto kompozíciu básnickej knihy môžeme nazerat aj ako na hru s recipientom textov. $\mathrm{V}$ tomto zmysle ju príznačne ukončuje posledná čast:: „rafinovane (parodicky?) si autor svoj debut rozvrhol! Hodlá začat' Prológom, no vzápätí ho prečiarkuje, pokračujúc Básňami, Automatickými textami a končiac dohodou Fair play s čitatel'om, kritikou a verejnostou“ (Žáry 1988: 24).

Literárna kritika sa spočiatku v zbierke Ut'até ruky snažila sledovat' prvky nadväzujúce na domácu literárnu tradíciu, no takisto zachytit jej novátorské postupy, ktoré však viacerí doboví recenzenti vzápätí odsudzovali: „Nájdete v nej 
554 všetky kunstgrify, ktoré podmieňujú výstavbu básnického textu zo stanoviska surrealistickej techniky: automatické texty, akoby jedným vrhom vyfúknuté zo vustenie vývinu slovenskej poézie, inšpirovanej okrem iného aj zahraničným vplyvmi, a rovnako za výraz konfliktu s tradíciou. Recepcia Fabryho debutu do istej miery určila podobu diskusie o ranej tvorbe nadrealistov. Napokon, heterogenita zbierky na to poskytovala množstvo podnetov.

Utaté ruky z názvu sú symbolickým vyjadrením nemožnosti uchopit (aj písaným slovom) skutočnost', no zároveň je tento obraz sám osebe jej silným (aj vizuálnym a senzualistickým) vyjadrením. Už názov teda vyjadruje princíp spočívajúci v existencii nadreality ako spojenia básnickej a každodennej reality. Ohlasujú sa v ňom tiež d'alšie nadrealistické princípy: prelínanie telesnosti a duchovného rozmeru, fragmentarizácia l'udského tela, predovšetkým ženského, a to za účelom jeho univerzalizácie a obsiahnutia ludskej podstaty v jej jedinečnosti i všeobecnosti. Možno identifikovat' aj apollinairovskú inšpiráciu z básne Rýnska jesenná: „Tot' drahé ruce navždy vychladlé / Tot'tvoje ruce ut'ate"“ (Apollinaire 2016: 117). Treba však povedat', že preberanie apollinairovských prvkov (takisto neskoršie, nie iba vo Fabryho debute) bolo v kontexte slovenského nadrealizmu odlišné od českej situácie: „Na Slovensku, kde sa k Apollinairovi sústavnejšie obracajú až nadrealisti okolo r. 1940, je situácia okrem toho komplikovaná tým, že pôsobí súčasne priamo i českým prostredníctvom a navyše sa aj kombinuje s prvkami vývinovo neskoršej surrealistickej poetiky. Intenzita apollinairovských impulzov a ich miesto vo vývine skúmaných literatúr sú teda značne rozdielne" (Winczer 1974: 111). Appolinairovský podnet $\mathrm{z}$ názvu Fabryho zbierky a takisto i d'alšie prítomné apollinairovské alúzie je preto nutné vnímat'v kontexte slovenského nadrealizmu a v kontexte vlastných inšpiračných zdrojov básnika, čiže cez prizmu toho, ako sa podnet adaptoval na Slovensku pre potreby domácej poézie. ${ }^{11}$

Z formálneho hl'adiska môže názov zbierky poslúžit ako vhodná ukážka pars pro toto nadrealistickej dôležitosti slova v celej jeho komplexnosti. ${ }^{12}$ Okrem evokovaného silného vizuálneho obrazu totiž slová z názvu pôsobia aj svojou krátkost'ou (dvoj- a trojslabičnostou) či opakovaným výskytom zadného vokálu „u“. Zvuková stránka textu zohrávala v nadrealizme absolútne klúčovú úlohu a aj experimenty s touto rovinou básne (riekankovitý rytmus, sémanticky zataženejšie aliterácie a rôzne typy rýmov, refrénové slovné spojenia a ich stmel'ovacia funkcia) sa stali podnetom $\mathrm{k}$ diskusii o novej podobe poézie, ktorú nadrealizmus priniesol.

11 O preberaní prvkov, ktoré nadrealizmus následne podrobil modifikácii, možno hovorit' aj v prípade takzvanej „elastickej slohy“, pri ktorej P. Winczer uvádza v porovnanís Vítězslavom Nezvalom parodický rozmer, ktorý jej pridal R. Fabry: „Fabry v básni Tri sny používa nezvalovský výstavbový princíp v rozpore so svojou pôvodnou funkciou a veršová forma sa dostáva do ostrého napätia až protirečenia s pretržitostou významovej línie, s alogickým narušením motivickej súdržnosti a prehodnocujúcimi schválnostami“ (Winczer 1974: 149).

12 „Základným stavebným materiálom nadrealistickej básne nie je metafora, obrazné pomenovanie, ako je to povedzme v symbolizme [...], ale samo slovo ako rovnocenný ekvivalent skutočnosti, slovo ako, tak povediac, skutočnost' sama“ (Šmatlák 1964: 20). 
Zbierka Ut'até ruky načrtla hranice slovenskej nadrealistickej poézie v ranej fáze jej vývinu. $\mathrm{V}$ jej d'alších fázach sa nadrealistickí autori vztahujú tak k tradícii (vracajú sa teda akoby dozadu), ako aj k inovácii (ked' sú nasmerovaní dopredu). Náznaky vykročenia za hranice konvencie v grafickej rovine Fabryho debutu - preškrtnutie textu či jeho zaliatie atramentovou škvrnou - pritom nie sú a priori inovatívnym postupom, v skutočnosti ich možno paralelne čítat ako odkaz na tradíciu - na písanie perom na papier, na ktorom sa bežne škrtá a kde sa niekedy vyleje náplň pera na text. ${ }^{13}$

Návraty k tradícii sú však viditel'né aj inde. I ked' sa vol'ný verš stal charakteristickým pre d'alšie Fabryho zbierky, v Utatých rukách básnik pracuje ešte stále do istej miery s formou viazaného verša, ktorého sa neskôr nadrealizmus postupne vzdáva. Inovácia vo veršovej rovine sa pritom formálne neprejavuje len vol'ným veršom, no tiež rôznymi spôsobmi varírovania foriem viazaného verša. R. Fabry pristupuje k tradícii tvorivo takisto v rámci tematického repertoáru, jeho „provokácie“ sú zaodeté do religióznych podtónov (aktualizovaná forma modlitby, litanickej chvály), tradícia a inovácia sa priam palimpsestovo prekrývajú. ${ }^{14}$

Akého umenia sa to teda Fabry programovo „vzdáva“v motte časti nazvanej Fair play? Toho, ktoré jeho tvorbe predchádzalo, alebo toho, za ktoré ju možno eventuálne označit'? Výrok „za cenu umenia vzdávame sa umenia“ sa dá čítat minimálne týmto dvojakým spôsobom, oproti revolte voči tradícii možno postavit' slobodu a deklarovanú programovú nezávislost' od označenia „umenie“. Fabry publikoval časopisecky už pred knižným vydaním svojej debutovej zbierky, preto je možné vnímat' motto aj ako d'alšiu etapu v procese jeho vlastnej tvorby, ako plné rozvinutie nových tvorivých princípov, ktoré boli naznačené v predošlých, časopisecky uverejnených textoch aj v prvých častiach zbierky Utaté ruky.

Latentne sexuálny podtón vlastný viacerým textom Ut'atých rúk (napríklad báseň Básnik) možno dešifrovat už vo Fabryho časopisecky publikovanej básni Cirkus: „V lampe zabudli na zlatú l'aliju / Večer v čiernom sene zvalí ju“ (Fabry 1934: 322). Rým tu plní funkciu vertikálnej metafory, ked'že rýmované slovo lalia ${ }^{15}$ (neskôr je tento symbol napríklad v Utatých rukách použitý v básni Tuláčky venovanej Rudolfovi Dilongovi) je so svojím symbolickým významom čistoty v protiklade k explicitnému pomenovaniu fyzického kontaktu - „zvalí ju“. Fyzické ohrozenie predstavuje v závere básne tiež had v klietke, z ktorej sa ozýva slávičí spev. Slávik sa nachádza nebezpečne v blízkosti hada, pričom toto nebezpečenstvo evokuje

13 Miloš Tomčík toto autorovo gesto interpretuje v duchu demonštratívneho odklonu od staršej poetiky: „vstupná čast' básnického debutu Rudolfa Fabryho Utáaté ruky, ktorú nazval mladý autor Prológom. Toto pomenovanie však graficky výrazne prečiarkol, aby dokázal, že síce ovláda poetiku starších básnikov, no že sa od nej dôsledne dištancuje. Fabry pretažil svoj básnický debut mnohými funkciami z hladiska prezentovania moderných básnických smerov v štruktúre svojej knihy. Sú tu zjavné súvislosti s dadaizmom, poetizmom i futurizmom“" (Tomčík 1987: 111).

14 „V Prológu je položený dôraz na intímnost' a lyrickost'. Je zaujímavé, že sa tu básnik pridržiava metódy staršej. Vidíme v tom nielen prehl'ad prekonanej básnickej epochy, ako by chcel Fabry sugerovat', ale aj výraz potreby, lebo mu nezostalo odvahy vysmievat' sa z tých kútikov vlastnej duše“ (Chorváth 1979: 213). 15 „Významy symbolu lalie závisia od kultúrneho kódu, cez ktorý je čítaný: čistota (purity), nesmrtel'nost' (immortality), ale aj plodnost' (fertility), túžba (desire); na margo ambivalencie symbolu slovník uvádza, že l'alie sa použivajú ako svadobné aj pohrebné kvety, pri hesle vodnej lalie (water-lily) sa uvádzajú možné významy plodnosti (fertility), ale zároveň aj čistoty (purity), pričom je vodná l'alia označená ako anti-afrodiziakum“ (Vries 1974: 298). 
556 už výber slov z predchádzajúcich sloh, ktoré po zvukovej stránke obsahujú konsonanty „,"“ a „l“: „zvali“, „plazi“, „zapleteny““. Slávik má u R. Fabryho takisto parodickú funkciu, v časti Prietrž v básni Smrt'slávikom a pinkavám sú napríklad verše: „Chcel by som byt'veršotepcom bez slávika / cáp cupi vel'ké krupy je ich málo / snád' by nám to jedno leto za to stálo / váś rozmarín zakrútil vetrmlýn“" (Fabry 1935:34). Podl'a Antona Popoviča sa tu stáva predmetom parodizovania ,inventár poklesnutej romanticko-symbolickej poézie, ktorú metonymicky reprezentuje slávik ako konštantný tematický prvok tradičného básnického arzenálu“ (Popovič 1970: 27). V básni Cirkus možno potom ohrozenie slávika hadom interpretovat' tiež ako tradičné básnické postupy a tematiku v strete s novou poéziou a jej hravým prístupom.

Hravá povaha Cirkusu sa zrkadlí vo zvukovej výstavbe Fabryho verša prostredníctvom hláskovej inštrumentácie aliterácií aj vnútorných rýmov: „Zebra predá rebrá za babku“ (Fabry 1934:322) či „Hýrivé výpary víria do neba“ (Fabry 1934: 322). V zbierke sa tieto postupy kombinujú so žánrovou formou hádanky, vypočítavanky, riekanky ako napríklad v básni Básnik: „Leze leze po železe / [...] / Leze leze po tele / panna sčerná v košele / on je 9 ona 6 / zachráňte jej svätú čest" (Fabry 1935: 22) alebo vo vyššie citovaných veršoch z básne Dievčenský popevok (Fabry 1935: 55). Tento formálny prvok si vyžaduje komplexné porozumenie autorovmu prístupu k daným žánrom a ich modifikácii, respektíve porozumenie novej funkcii, ktorú nadobúdajú v tvorbe R. Fabryho. Ide o syntézu tradičnej ludovej tvorivosti a novej poézie, ${ }^{16}$ pričom nová funkcia akoby sa vrstvila na pôvodnú - neneguje ju, pracuje s ňou kreatívne. Napríklad rytmus rečňovanky, ktorý mal pôvodne funkciu vypočítavania v rámci detskej hry, sa dostáva do roviny počítania obetí vojny. Na rovnakom princípe funguje preberanie atmosféry žánru: na konci rečňovanky niekto vypadol $\mathrm{z}$ hry, ide o budovanie napätia, $\mathrm{k}$ tomu dochádza aj v prípade posunutia žánru do zobrazenia vojnového ohrozenia. V. Turčány interpretuje vo Fabryho básni Básnik inšpiračný zdroj z ludovej tvorivosti cez prizmu sekundárneho významu, ktorý v nadrealistickej básni nadobúda svojou aktualizáciou. V tejto súvislosti píše: „prvý verš je prebraný z ludovej hádanky, no rýmom spätný verš hned'aj ,kvalifikuje', znehodnocuje riekankovitost' samu o sebe, ak sa nechápe jej skrytý, jedine správny význam“ (Turčány 1975: 201).

Snaha situovat'Ut'até ruky R. Fabryho do kontextu slovenského nadrealizmu vyzdvihuje vnútornú protirečivost' tohto obdobia, ktorú v sebe autenticky odrážalo aj autorovo písanie. To oscilovalo medzi inováciou a tradíciou, čo bol moment príznačný pre úvodnú fázu nadrealizmu v slovenskej literatúre. Nadrealistické gesto je tu zat'ažené sekundárnymi významami. Či už ide o básne s protivojnovou alebo l'ahko erotickou tematikou, forma detskej riekanky či iného žánru nie je použitá len ako kontrast k takýmto témam. Samotná forma (najmä repetitívnost' a rytmickost') vytvára istý druh atmosféry sekundárneho strachu, úzkosti, neprijemných, sklučujúcich pocitov. Nadrealistická podoba hry s formou básne obsahovala viacero vrstiev. Postupne sa stávala súčast'ou nadrealistickej

16 „Najmä ,modely` krátkych rečňovaniek mali dokumentovat autorovo poňatie poézie ako hry, obraznej invencie, ktorá jednej časti kritikov prekážala, kým iní nachádzali v tejto hre so slovami a obrazmi súvislosti s prototypom l'udových piesní. Vtipne na to poukázal Alexander Matuška v replike o nadrealizme na Kongrese slovenských spisovatel'ov v Trenčianskych Tepliciach r. 1936, ked'povedal: ,U nás sa nadáva na surrealizmus. Kto však bude hl'adat', určite nájde v slovenských ludových piesňach veci, ktoré surrealizmus nie sú, ale kde sa bezstarostne spieva: Mala som frajera ako hus bieleho““ (Tomčík 1987: 111). 
umeleckej skutočnosti, ale aj následnej diskusie o nej. Vymedzenie sa voči automatickému písaniu a iným surrealistickým metódam, ktoré kritika v súvislosti so slovenským nadrealizmom uvádzala, spočívalo aj v predstavení vlastnej, originálnej formy hravosti.

\section{Experiment ako estetická a poetologická kategória}

Vizuálny charakter Ut'atých rúk znamenal podl'a Jána Kraloviča „,radikálne gesto popretia či subverzie klasického textu" (Kralovič 2018:338). Z literárneho hladiska možno na takéto gesto nazerat' ako na preskupenie vztahov či prelínanie skutočnostných rovín: „Fabryho tvorba nás tu zaujímala ako najradikálnejší básnický prejav slovenského nadrealizmu. Všímali sme si ju z hladiska jej novosti v slovenskej poézii, a nie z hl'adiska jej hodnoty. Estetická hodnota Fabryho tvorby nespočíva, prirodzene, $\mathrm{v}$ odvahe pri lámaní konvencií, teda v deštrukcii. Spočíva v originalite pri objavovaní nových vztahov" (Winczer 1974: 107).

Za krédo nadrealistov vyhlasoval V. Reisel jednoducho túžbu byt' proti zlu. Za toto zlo je možné spätne dosadit' okrem neslobodnej politickej situácie aj neslobodu spoločenskú či neslobodu vo vzt'ahu k básnickému experimentu. Voči tomu sa nadrealisti vymedzovali okrem iného aj zosilneným prepojením literárnej tvorby s umeleckým životom ako takým. Vzájomnost' autorov posilňovala silu ich umeleckého vyjadrenia. Umenie cielene vstupovalo do širších súvislostí verejného priestoru. Nadrealistické zborníky v sebe niesli potenciál stat' sa predmetom diskusie (napríklad diskusia o protifašistickej orientácii zborníka Áno a nie z roku 1938).

Dôležitú úlohu pri básnickom sebavyjadrení zohrávala aj v období nadrealizmu sloboda experimentovat', možnost' narušit' konvencie v neslobodnej spoločensko-politickej situácii. Isté charakteristiky pripisované nadrealistickej poézii priamo vyplývajú z okolností, v ktorých táto poézia vznikala. Možno tvrdit', že zdanlivo nelogická tvorba nadrealistov bola odrazom vnútorne protirečivej doby. Kritika nadrealistickej tvorby videla neraz práve v domnelej experimentálnej podstate tejto poézie prostriedok jej negatívneho hodnotenia. Slovenský nadrealizmus bol nevhodne analogicky porovnávaný so surrealizmom českého alebo francúzskeho typu, hoci nadväzoval na slovenskú básnickú tradíciu. ${ }^{17}$ Je však namieste položit' si otázku, čo tvorilo danú „slovenskú básnickú tradíciu“ a do akej miery bolo možné na ňu nadväzovat', respektíve akým spôsobom (a či akýkol'vek spôsob neobsahoval experiment či provokáciu automaticky v sebe): , Je pochopitel'né, že na pozadí určitej štruktúrnej amorfnosti slovenskej poézie ako celku musela vyznievat' každá striktná novota dost' provokatívne. [...] nemožno sa príliš čudovat', že moment prekvapenia, sprevádzajúci ,vpád‘ surrealizmu do slovenskej poézie, viedol v krajných prípadoch k vyhlasovaniu tohto vpádu za umelecký podvod a prejav šarlatánstva“ (Šmatlák 1964: 19). Ambivalencia nadrealistického gesta experimentu spočiva $v$ prepojení zdanlivo protichodných prístupov, konkrétne $\mathrm{v}$ spojení nehateného experimentu a racionalizmu.

17 „Nadrealisti vychádzajú zo slovenskej básnickej tradície, i ked'ju radikálne popreli, ich snahy zapadajú do vývinu slovenskej lyriky a sú organickým pokračovaním v hl'adaní jej nových výrazových možnosti“" (Považan 1942: 180). 
„Lyrika Fabryho má tiež silne experimentálny charakter; jeho metoda je na pozadí slovenskej poezie silne zdôraznená, odhalená, vystupujúca. Vo vyslovene experimentálnych číslach (na konci knihy) badat' snahu o zmierenie kontrastu medzi dispozíciami, danými tradíciou a nárokmi, kladenými básnikom. Pre tieto experimenty Fabry hladá realistickú motiváciu: písací stroj - pokazený, dopis (sám o sebe dost' náročný a ,nerealistický) zásahom náhody (ktorá je inak u surrealistov obvyklý deus ex machina) mení sa v najbizarnejší výtvor fantázie“ (Bakoš 1936: 217).

Dostáva sa tu k modelu experimentu s realistickou motiváciou, ktorý akoby bol výsledkom snahy legitimizovat' experimentovanie v nadrealistickej poézii, v závere sa však nezaobíde bez zásahu surrealistickej náhody.

Nadrealizmus potrebuje tradíciu ako svoj porovnávací základ, kontrastné pozadie, vd'aka ktorému môže vyniknút jeho jedinečnost'. Vzt'ah inšpiračných zdrojov z domácej literárnej tradície a experimentálnych zdrojov zahraničnej proveniencie je vzt'ahom dynamickej rovnováhy. Otvorené prijatie tejto dynamickosti je jedným z krokov, ktoré môžu skúmanie nadrealizmu posunút vpred. Nadrealizmus sa vo výsledku javí nie ako slovenská verzia surrealizmu, ale skôr ako proces hladania možností tvorivého využitia impulzov surrealizmu českého a francúzskeho typu pri súčasnom kreovaní podoby novej poézie v slovenskej literatúre.

\section{Nadrealizmus ako viacdimenzionálny kultúrny fenomén}

Aktuálne výskumy tvorby R. Fabryho ukazujú na potrebu vnímat' ju ako neoddelitel'nú súčast' nadrealistického gesta, pokusu viest' dialóg so spoločnost'ou a s dobou, v ktorej dané diela vznikali. Nazeraním Fabryho tvorivej činnosti touto optikou sa otvára aj možné hl'adisko vnímania nadrealizmu v jeho celistvosti - nielen ako literárneho smeru, ale aj ako viacdimenzionálneho hnutia, ktorého performancie a tvorivé počiny opakovane prekračovali hranice vtedajšej podoby poézie aj iných druhov umenia. Sociologický koncept siete väzieb, prostredníctvom ktorého je možné objasnit'vzt'ahy medzi jednotlivými autormi nadrealistického okruhu a ich spolupracovníkmi z oblasti výtvarného umenia, zrkadlí túto viacdimenzionálnost' a ukotvuje ju vo fyzickom priestore kaviarne, ateliéru, prípadne iných miest stretnutí zúčastnených umelcov. Diela tak pri svojej interpretácii vystupujú v celistvom kontexte dobovej reality, nie ako izolované elementy tvorby toho-ktorého autora. Vzájomná previazanost' literárnej a výtvarnej scény je doplnená o živý umelecký dialóg, ktorý ju sprevádzal a ktorý je až dodnes v mnohom klúčom k spoznaniu miesta jeho aktérov v nadrealistickej mozaike. 
APOLLINAIRE, Guillaume, 2016. Alkoholy. Praha: Garamond.

DEDINSKÝ, Móric Mittelmann, 1936. Krivky. Bratislava: Aligátor.

FABRY, Rudolf, 1934. Cirkus. Slovenské smery umelecké a kritické, roč. 2, č. 2, s. 322.

FABRY, Rudolf, 1935. Utaté ruky. Bratislava: Aligátor.

REISEL, Vladimír, 2017. Vidím všetky dni. Bratislava: Marenčin Media. ISBN 978-80-8114-903-0.

ŽÁRY, Štefan, 1988. Rande s básnikmi. Bratislava: Slovenský spisovatel'.

\section{Literatúra}

BAKOŠ, Mikuláš [BAKOŠ, Nikolaj], 1936. Surrealizmus na Slovensku a čo s tým? Slovenské smery umelecké a kritické, roč. 3, č. 3, s. 211-221.

DEDINSKÝ, Móric Mittelmann, 1963. Poznámky k histórii, vzniku a vývinu slovenskej literárnej avantgardy. Slovenské pohl'ady, roč. 79, č. 3, s. 26-40.

DUBNICKÝ, Jaroslav, 1941. K otázke vztahov medzi nadrealistickou poéziou a výtvarným umením mladej generácie. In Vo dne a v noci. Bratislava: Skarabeus, s. 142-146.

FELIX, Jozef, 1938. Rudolf Fabry: Vodné hodiny hodiny piesočné. In FELIX, Jozef. Kritické rozlety. Bratislava: Slovenský spisovatel', s. 168-174.

FERGUSON, Niall, 2019. Věž a náměstí. Přeložil Jan M. Heller. Praha: Argo, ISBN 978-80-257-3047-8, 978-80-7363-978-5.

CHORVÁTH, Michal, 1979. Rudolf Fabry: Utáaté ruky. In CHORVÁTH, Michal. Cestami literatúry. Bratislava: Slovenský spisovatel', s. 212-214.

KRALOVIČ, Ján, 2018. Nadrealizmus a ilustrácia. In Pribehy pamiatok a obrazov. Zborník príspevkov k sedemdesiatinám Ivana Gojdiča. Trnava: Typi Universitatis - Bratislava: Veda, s. 338-349. ISBN 978-80-568-0152-9.

LONGAUER, L'ubomír, 2011. Modernost'tradície. Úžitková grafika na Slovensku po roku 1918. Bratislava: Slovart. ISBN 978-80-556-0331-5.

MIKULA, Valér, 2014. Diletantstvo ako „básnický“ princíp. In MIKULA, Valér. Postinterpretácie. Bratislava: Cathedra, s. 113-123. ISBN 978-80-89495-16-0.

POPOVIČ, Anton, 1970. Štrukturalizmus v slovenskej vede. Martin: Matica slovenská.

POVAŽAN, Michal, 1942. Vývinové zaradenie nadrealistickej poézie. In POVAŽAN, Michal. Novými cestami. Kritiky, štúdie, prejavy. Bratislava: Slovenský spisovatel', s. 179-197.

ŠMATLÁK, Stanislav, 1964. Úvod k úvodu do nadrealizmu. Slovenské pohl'ady, roč. 80, č. 9, s. 18-21.

TOMČÍK, Miloš, 1987. Tvorba a kritika. Bratislava: Tatran.

TURČÁNY, Viliam, 1975. Rým v slovenskej poézii. Bratislava: Veda.

VRIES, Ad de, 1974. Dictionary of Symbols and Imagery. Amsterdam: North-Holland Publ. Comp.

WINCZER, Pavol, 1974. Poetika básnických smerov. Bratislava: Veda.

Mgr. Jaroslava Šaková, PhD.

Ústav cudzích jazykov

Lekárska fakulta

Univerzita Komenského v Bratislave

Moskovská 2

81108 Bratislava

Slovenská republika

E-mail: jaroslava.sakova@fmed.uniba.sk 